\title{
The Effect of the Transtheoretical Model Approach Towards the Body Mass Index of Overweight and Obese Children in Makassar
}

\author{
Kadek Ayu Erika ${ }^{1, *}$ \\ ${ }^{1}$ Department of Pediatrics, Nursing Program, Faculty of Medicine Hasanuddin University, Jl. Perintis Kemerdekaan Km.10, Makassar, Indonesia \\ *Corresponding author. E-mail: kadek20_uh@yahoo.com
}

\section{Abstract}

B ACKGROUND: Overweight and obesity is now ranked fifth as a global risk for the cause of death. Urban lifestyle is fueled by excessive food intake and lack of activity in overweight and obese children. The assessment of the children's Body Mass Index (BMI) is one of the indicators to assess the nutritional status of children. One strategy that can be used is the transtheoretical model (TTM) approach which is behavior change that helps children and parents in making more effective decisions to reduce health-risk behaviors among children so that the children's BMI can decrease. This study aims to identify the differences between children's BMI before and after the TTM approach.

METHODS: This research was conducted in the district area of Tamalanrea and Biringkanaya, Makassar. The design used is the Quasy Experiment namely pre- and post-test with control group design. Research subjects were overweight or obese children in the $4^{\text {th }}, 5^{\text {th }}$, and $6^{\text {th }}$ grade of elementary school. The samples in the treatment group consisted of 31 participants, while the control group consisted of 33 participants which were selected using purposive sampling. Intervention research was conducted during a six month period by providing guide books on healthy lifestyle, visiting the families every month using questionnaires, and measurements of children's height, weight and BMI using WHO's AntrhoPlus software year 2007.

RESULTS: Post-pretest results showed the average value of the treatment group's BMI was $-1,48$ and the control group was 1,35 . This means that the treatment group experienced a decrease in BMI after the application of TTM. The Mann Whitney test results indicate that there is a difference in the BMI pre-post intervention with the value of $\mathrm{p}=0.00(>0.05)$.

\section{Abstrak}

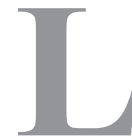

ATAR BELAKANG: Overweight dan obesitas sekarang merupakan peringkat kelima sebagai risiko global untuk terjadinya kematian. Gaya hidup perkotaan dipicu oleh asupan makanan yang berlebih dan aktivitas kurang pada anak overweight dan obesitas. Penilaian Indeks Massa Tubuh (IMT) pada anak merupakan salah satu indikator untuk menilai status gizi anak. Salah satu strategi yang dapat digunakan adalah dengan pendekatan transtheoretical model (TTM) yaitu perubahan perilaku yang membantu anak dan orang tua dalam membuat keputusan yang lebih efektif untuk mengurangi perilaku risiko masalah kesehatan pada anak sehingga IMT anak dapat menurun. Penelitian ini bertujuan untuk mengidentifikasi perbedaan IMT anak sebelum dan setelah pendekatan TTM.

METODE: Penelitian ini dilaksanakan di wilayah kecamatan Biringkanaya dan Tamalanrea, Makassar. Desain yang digunakan adalah Quasy Eksperiment yaitu pre- and post-test dengan control group design. Subyek penelitian adalah anak overweight atau obesitas kelas 4, 5 dan 6 SD. Jumlah sampel sebanyak 31 pada kelompok perlakuan dan 33 kelompok kontrol yang dipilih secara purposive sampling. Intervensi penelitian 6 bulan dengan pemberian buku panduan gaya hidup sehat, mengunjungi keluarga tiap bulan dengan menggunakan kuesioner, pengukuran berat badan dan tinggi badan anak serta IMT dengan WHO AntrhoPlus software tahun 2007.

HASIL: Hasil post-pretest menunjukkan nilai rerata IMT kelompok perlakuan adalah -1,48 dan kelompok kontrol adalah 1,35. Artinya kelompok perlakuan mengalami penurunan IMT setelah aplikasi TTM. Hasil uji Mann Whitney terdapat perbedaan IMT pre-post intervensi dengan nilai $\mathrm{p}=0.00(<0.05)$. 
CONCLUSION: The overweight and obese children's BMI was influenced by TTM approach.

KEYWORDS: transtheoretical model, children's BMI, overweight, obesity

Indones Biomed J. 2014; 6(1): 51-6
KESIMPULAN: Terdapat pengaruh pendekatan TTM terhadap IMT anak overweight dan obesitas.

KATA KUNCI: transtheoretical model, IMT anak, overweight, obesitas

\section{Introduction}

Overweight and obesity is now ranked fifth global risk for the cause of death. There were $44 \%$ cases of diabetes, $23 \%$ cases of ischemic heart disease and 7-41\% cases of cancer that were caused by overweight and obesity. Prevalence of overweight and obesity in children is estimated to be 35 million children in developing countries compared to the 8 million in developed countries.(1) Based on the National Youth Risk Behavior Survey (YRBS) in 1999 to 2011 of school children aged 9-12 years, the prevalence of obesity has increased from 10.6 to $13 \%$, while overweight increased from 14.2 to $15.2 \%$.(2) Obesity is a problem that is happening in developing countries, including Indonesia. Indonesian society, especially in big cities is experiencing public health problems triggered by the presence of excess nutrients and less physical activity during childhood. $(3,4)$ Research conducted by Mushtaq et al. found that lifestyle including watching television, working on the computer and playing video games showed a significant association with high Body Mass Index (BMI) and the risk of being overweight.(5)

Based on the BMI, the prevalence of overweight children aged 6-14 years in Indonesia were 9.5\% in males and $6.4 \%$ in females, while in South Sulawesi the numbers were $7.4 \%$ in males and $4.8 \%$ in females. The prevalence of weight tended to be based on gender, in which there was a slightly higher percentage of heavier children in urban areas, with $10.6 \%$ in males in urban areas, $8.8 \%$ in males in rural areas and $7.1 \%$ in females in urban areas, $6.0 \%$ in females in rural areas.(6) The data of school-age children's weight by Riskesdas in (2010) are as follows: prevalence of nutritional status (BMI/U) of obese children aged 6-12 years in Indonesia was $9.2 \%$ which is higher than the $4.6 \%$ of children who were categorized as underweight and $7.6 \%$ of children categorized as skinny. In addition, obese children based on gender amounted to $10.7 \%$ in males and $7.7 \%$ in females. Based on the area, the number of obese children in cities was $10.4 \%$ and in rural areas $8.1 \%$. Meanwhile, overweight children in South Sulawesi amounted to 3.9\%.
Based on the data obtained by Riskesdas (2010), it can be concluded that there was an increase of body weight in school-age children by gender which occured in urban areas.(7)

Effects of obesity among children includes breathing difficulty, Obstructive Sleep Apnea (OSA), an increased risk of bone fracture, hypertension, an increase of blood cholesterol, early signs of cardiovascular disease (CVD), metabolic syndrome, dyslipidemia, type 2 diabetes mellitus, insulin resistance, polycystic ovary syndrome, cholelithiasis and psychological effects.(8) Overweight and obesity also affects child development including psychosocial aspects. $(9,10)$ This is consistent with studies our previous report showing that lifestyle and obesity contribute to the incidence of pre-diabetes as an early sign of asymptomatic type 2 diabetes.(11)

Thus, through health education in child care, the majority of parents $(81 \%)$ believed that handouts will be enough or a very useful way to receive information on health in order to increase parental knowledge (12). The committee of experts recommended to the patient and family to pay attention to their food intake, physical activity and sedentary behavior.(13) Based on the above situation, the strategy that can be used is the transtheoretical model (TTM) approach which is behavior change that helps children and parents in making more effective decisions to reduce health-risk behaviors of overweight and obese children, as well as increasing healthy behaviors. TTM consists of four core constructs namely stages of change, processes of change, decisional balance, and self-efficacy. The stages of change is comprised of 5 stages which are precontemplation, contemplation, preparation, action and maintenance. This study used the action stage in which children were already prepared to undergo the 6 month intervention to decrease the child's BMI (14). This is in line with the research studies conducted by Tuah et al. which assessed the use of Stage of Change (SOC) TTM in overweight and obesity management program for weight loss and dieting as well as behavior change in physical exercise.(15)

This study aims to identify the differences between child BMI before and after the TTM approach. 


\section{Methods}

The research design used was the "Quasy-experiment", namely pre- and post-test with control group design. The study was conducted from August 2013 until March 2014 in the district area of Tamalanrea and Biringkanaya, Makassar. The treatment group was given health education interventions for 6 months through the TTM approach, by providing guide books and leaflets on healthy lifestyle to children with excess body weight. The guide books and leaflets contained information about overweight and obesity as well as healthy lifestyle recommendations including: children's physical activity, advice for children's diet and healthy lifestyle behaviors, example of a healthy one day menu for children aged 9-12 years which includes child lifestyle monitoring sheet, and an example of substitute foods and BMI chart. At the same time, the control group was not given intervention. Subjects in the control group were only given leaflets. Research subjects were overweight or obese children in the $4^{\text {th }}, 5^{\text {th }}$ and $6^{\text {th }}$ grade of elementary school and their parents who were selected using purposive sampling method, which is a method to select samples that meet the inclusion criteria. The total sample size obtained using this method was 64 people, 31 of whom were placed in the treatment group and the remaining 33 in the control group.

Both male and female, Buginese or Makassarese subjects who are Muslims and are at the action stage were willing and have filled out the informed consent. Subjects were removed from the study if they did not follow the whole research procedure, if the child became seriously ill, or if the family changed residence. This study has been approved by the Ethics Review Committee of the Faculty of Medicine of Hasanuddin University, and all subjects were asked for their consent to participate in the study.

Questionnaires were filled out by direct interview which was conducted by a team who has been previously trained on biographical data, decision balance, and selfefficacy that has been tested for validity and reliability. All samples that were selected were then measured by a trained team of 4 people. The measurements conducted include measurement of weight and height. Then, to determine the child's BMI the WHO AntrhoPlus software based on WHO, 2007 for children aged 5-18 years was utilized. Statistic analysis was completed using SPSS for Windows version 16.0 with a significance level of $p<0.05$. Differences in BMI between treatment and control groups after the intervention was analyzed using independent t-test and Mann-Whitney.

\section{Results}

The results, as shown in Table 1, indicate that between the treatment group and the control group there was an equality/ homogeneity. Results of the test of homogeneity between the treatment and control groups on the children's gender obtained the value of $p=0.313$, on the father's education obtained the value of $p=0.856$, mother's education obtained the value of $p=0.453$, family income obtained the value of $p=0.329$, parental history of obesity obtained the value of $p=0.694$, family health history obtained the value of $p=0.306$, and family structure obtained the value of $p=0.112$.

Figure 1 shows the measurement results of the pretreatment group which consisted of 31 children (100\%). There were 7 children $(22.6 \%)$ with their nutritional status categorized as overweight and 24 children (77.4\%) categorized as obese. Whereas in the control group of 33 children (100\%), there were 26 children (78.8\%) with their nutritional status categorized as overweight and 7 children $(21.2 \%)$ categorized as obese. After the intervention was conducted for 6 months, there was a change in the nutritional

Table 1. Analysis of the characteristics of respondents in the treatment and control group.

\begin{tabular}{|c|c|c|c|c|c|}
\hline \multirow{3}{*}{ Characteristics of respondents } & \multicolumn{4}{|c|}{ Group } & \multirow{3}{*}{$p$} \\
\hline & \multicolumn{2}{|c|}{ Treatment } & \multicolumn{2}{|c|}{ Control } & \\
\hline & n (31) & $\%$ & n (33) & $\%$ & \\
\hline \multicolumn{6}{|l|}{ Gender } \\
\hline - Male & 18 & 58.1 & 15 & 45.5 & 0.313 \\
\hline - Female & 13 & 41.9 & 18 & 54.5 & \\
\hline \multicolumn{6}{|l|}{ Father's education } \\
\hline - High & 20 & 64.5 & 22 & 66.7 & 0.856 \\
\hline - Low & 11 & 35.5 & 11 & 33.3 & \\
\hline \multicolumn{6}{|l|}{ Mother's education } \\
\hline - High & 14 & 45.2 & 18 & 54.5 & 0.453 \\
\hline - Low & 17 & 54.8 & 15 & 45.5 & \\
\hline \multicolumn{6}{|l|}{ Family income } \\
\hline - High & 31 & 100 & 32 & 97 & 0.329 \\
\hline - Low & 0 & 0 & 1 & 3 & \\
\hline \multicolumn{6}{|l|}{ Parental history of obesity } \\
\hline - Yes & 29 & 93.5 & 30 & 90.9 & 0.694 \\
\hline - No & 2 & 6.5 & 3 & 9.1 & \\
\hline \multicolumn{6}{|l|}{ Health History } \\
\hline - High risk family & 22 & 71 & 27 & 81.8 & 0.306 \\
\hline - Non high risk family & 9 & 29 & 6 & 18.2 & \\
\hline \multicolumn{6}{|l|}{ Family Structure } \\
\hline - Main family & 26 & 83.9 & 22 & 66.7 & 0.112 \\
\hline - Extended family & 5 & 16.1 & 11 & 33.3 & \\
\hline
\end{tabular}




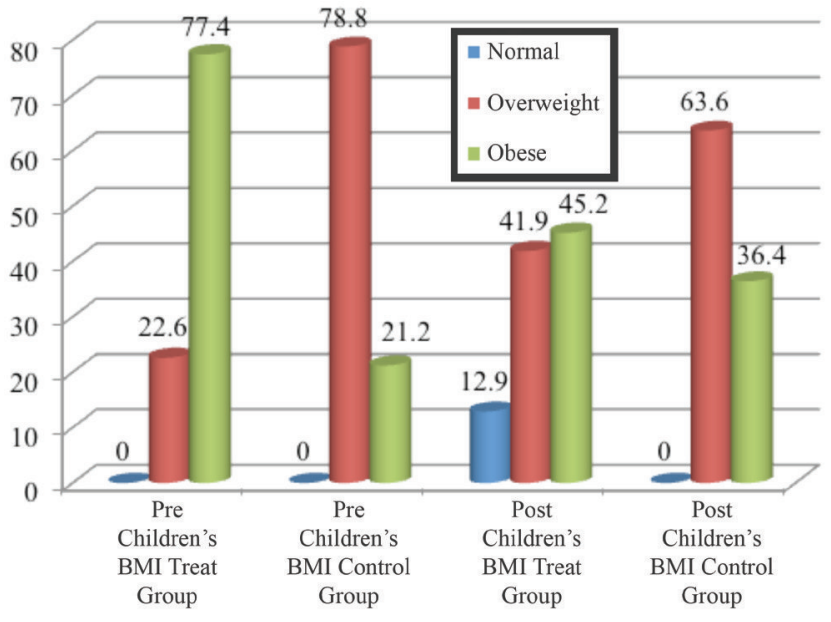

Figure 1. Children's nutritional status distribution based on children's BMI.

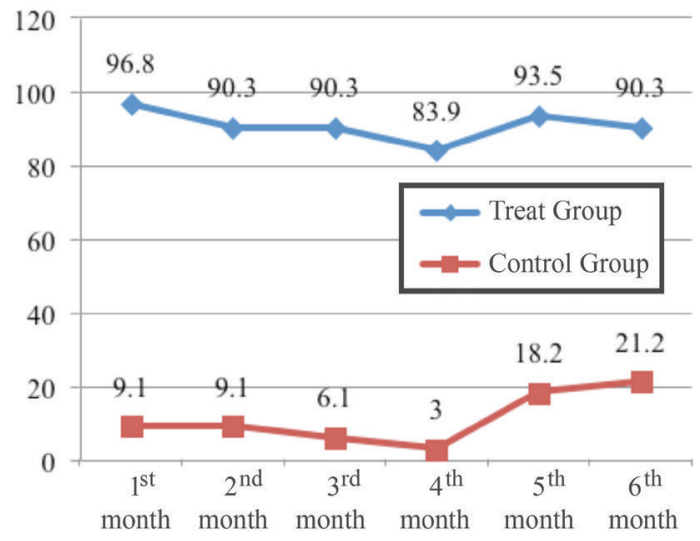

Figure 2. Changes in children's BMI reduction.

status of the children in both groups. The treatment group has 4 children (12.9\%) categorized as normal range, 13 children (41.9\%) categorized as overweight, and 14 children $(45.2 \%)$ categorized as obese. While in the control group, there were 21 children (63.6\%) categorized as overweight and 12 children (36.4\%) categorized as obese.

Figure 2 presents a graph showing changes of BMI reduction in children in the treatment and control groups each month during a six-months period. It is evident that the children in the treatment group experienced a BMI reduction as much as $90.3 \%$ on the sixth month. Meanwhile, the children in the control group only experienced $21.2 \%$ in BMI reduction on the sixth month.

From the data in Table 2, it can be seen that the mean value of changes in children's BMI in the control group after six months was 1.35 and the mean value of changes in the treatment group was -1.48 , which signifies that the treatment group experienced a decrease in children's BMI. Mann Whitney test results show the value of $p=0.00$, which means there are differences in the mean of the pre-post BMI changes in the treatment and control group, so that the TTM approach does affect the children's BMI reduction.

\section{Discussion}

Changes in children's BMI after health education intervention using guide books, showed that there was a difference in children's BMI before and after the intervention of the TTM approach on the treatment group. This is in line with research conducted by Tuah et al. who found that the use of SOC TTM in overweight and obesity management programs were effective in reducing weight (15). In addition, research by Johnson et al. on overweight and obese adults (BMI 25-39.9, $\mathrm{n}=1277$ ) with multiple behavior interventions, demonstrated the ability of the TTM to effectively increase healthy eating, exercising, and managing of emotional distress as well as weight. The impact of multiple behavior intervention is three times bigger than single behavior interventions.(16) Health promotion/prevention of overweight and obesity by a mentor is also effective in preventing an increase in BMI and in reducing snacks/desserts consumption.(17)

Foster et al. found that multicomponent intervention was effective in preventing the development of overweight

Table 2. Differences in children's BMI in the treatment and control group based on the observation time.

\begin{tabular}{|c|c|c|c|c|c|c|c|}
\hline \multirow{2}{*}{ Observation Time } & \multirow{2}{*}{ Group } & \multicolumn{5}{|c|}{ Children's BMI Values } & \multirow{2}{*}{$p$} \\
\hline & & Mean & Min & Max & Med & SD & \\
\hline \multirow{2}{*}{ Pre test } & Treatment & 24.08 & 19.94 & 30.21 & 23.42 & 2.83 & \multirow{2}{*}{$0.00^{*}$} \\
\hline & Control & 21.72 & 19.15 & 27.92 & 21.32 & 2.09 & \\
\hline \multirow{2}{*}{ Post Test } & Treatment & 22.59 & 18.39 & 28.76 & 21.88 & 2.93 & \multirow{2}{*}{$0.46^{*}$} \\
\hline & Control & 23.07 & 20.34 & 29.38 & 22.88 & 2.12 & \\
\hline \multirow{2}{*}{$\begin{array}{l}\text { Changes } \\
\text { (Post-Pre) }\end{array}$} & Treatment & -1.48 & -2.4 & 1.29 & -1.57 & 0.64 & \multirow{2}{*}{$0.00 * *$} \\
\hline & Control & 1.35 & 0.39 & 3.11 & 1.23 & 0.61 & \\
\hline
\end{tabular}

* Independent t-test; ** Mann Whitney 
and obesity in children in the $4^{\text {th }}$ to $6^{\text {th }}$ grade of elementary schools in urban areas (18). The necessity of communitybased partnerships to integrate health care, education, environment, government, and business was reported by McCarron et al.(19) While Golan and Weizman (2001) recommended a family-based conceptual model that emphasizes on healthy lifestyle that will eventually result in weight loss.(20)

According to Watson, to improve health, one must restore the health of the client and prevent pain (21), so that the caring behavior of parents is very important in preventing the effect of the disease in obese children. Williamson and Kautz put forward a program to raise the awareness of African-American students that obesity can increase the risk of heart disease and diabetes.(22) Jones et al. stated that the effectiveness of the health information technology and health literacy program to raise awareness about the health risks of obesity among African-American students is very beneficial.(23)

Overweight and obese children as well as their parents need health promotion and health care from an early age to prevent the effects of OSA that will cause endothelial dysfunction through the increased oxidative stress mechanism that may also increase the risk of CVD.(24) The relationship between obesity, inflammation, and the risk of atherosclerosis is supported by a study conducted on obese children in Turkey aged 4.5 to 15 years old through their adolescence. The study showed that there was a positive correlation of high sensitivity - C Reactive Protein (hs$\mathrm{CRP}$ ) with BMI, relative body weight, blood pressure, and serum leptin.(25)

A study examined the application of adult criteria for diagnosis of metabolic syndrome in Turkish children aged 10-17 years old which showed that $2.2 \%$ had metabolic syndrom.(26) The results of this study found that metabolic syndrome is a problem that occurred almost 10 times more common among overweight and obese students (21\%) than leaner students. Meanwhile, the prevalence of metabolic syndrome was $5.6 \%$ in overweight and obese pre-puberty children (8-10 yrs) in Costa Rica. An increased risk of metabolic syndrome was also reported among obese adolescents (11-20 yrs) in Argentina with an Odds Ratio of $(\mathrm{OR})=119.73$ (27). High prevalence of the metabolic syndrome has also been reported in 10-19 years old adolescents in Iran by $10.1 \%$ (28) and in obese children in Bolivia aged 5-18 years by $36 \%$ (29).

This study showed that the BMI in both groups experienced a decrease on the sixth month, with the BMI in the treatment group reduced by $90.3 \%$ compared to the control group that only decreased by $21.2 \%$. Interventions were given in the form of a healthy balanced menu based on age, physical activity for one hour every day and child health behaviors according to Barlow who recommended that children and families pay attention to their food intake, physical activity and sedentary behavior.(13) Research conducted by Mushtaq et al. showed that the physical activity and lifestyle of school children in Pakistan were independent predictors of overweight and obesity.(5) Lifestyle that includes watching television, working on the computer and playing video games showed a significant association with high BMI and the risk of overweight (OR: $1.60)$ as well as the risk in children with a higher BMI.

In this study, based on the nutritional status of children in the treatment group after the intervention was conducted, the number of obese children fell from 24 to 14 children, overweight children from 7 to 13 and leaving 4 children with a normal nutritional status. This study demonstrated that TTM intervention approach greatly influenced the reduction in child BMI and child nutritional status change for the better. This is because the content of the module was equipped with information on healthy lifestyle and child monitoring sheets that represents the role of culture care repatterning so that families are able to control the physical activity and food intake of their children. In addition to the increase of physical activities done by children after the intervention in the treatment group, the data showed a decrease in BMI as high as $96.4 \%$.

On the other hand, there are still subjects in the treatment group who did not experience a decrease of BMI. It was concluded that this result occured because of a lack of children's activities, especially during the rainy season, in which children spend more time at home playing games or watching television. Children also still liked to snack on food or drinks at school or outside the house. As a result, parents could not control the child's food intake outside the house.

Changes in children's BMI is a motivation for children to change to a healthier lifestyle. The motivation to lose weight in children is the key to success, this is because school-age children begin to gain the ability to weave a number of events and activities, children become physically mature, they become curious and ask many questions about health.(30) Thus, the role of the family is to control their children's lifestyle by doing more physical activity which has resulted in the decrease of the children's BMI in the treatment group after the implementation of TTM approach. 


\section{Conclusion}

The results of this study showed that there were differences in the average change in BMI of children (in the 4t, 5th and 6th grade of elementary school located in Tamalanrea, Makassar 2014) in the treatment and control group. This study has also demonstrated that the TTM approach has indeed influenced children's BMI. Future researchers could use other intervention medias such as electronic medias: videos, mobile phone containing a healthy lifestyle program for children and their family, especially overweight and obese children. Intervention could also be done during a longer period of time and by using more samples as well as developing other variables.

\section{References}

1. World Health Organization (WHO). Population-based prevention strategies for childhood obesity: report of a WHO forum and technical meeting. Geneva: Department of Child and Adolescent Health and Development. 2010.

2. Centers for Disease Control and Prevention (CDC). Trends in the prevalence of obesity, dietary behaviours, and weight control practices national YRBS : 1991-2011. 2011; (Online). (www.cdc. gov/yrbss, retrieved 7 April 2013).

3. Hamam, H. Gizi lebih sebagai tantangan baru dan implikasinya terhadap kebijakan pembangunan kesehatan nasional. The Indonesian Journal of Clinical Nutrition. 2004; 1(2).

4. Wong, D.L. Wong and Whaley's Clinical Manual of Pediatric Nursing, 4th Edition. Missouri: Mosby Inc. 2004.

5. Mushtaq, M.U., Gull, S., Mushtaq, K., Shahid, U., Shad, M.A., \& Akram, J. Dietary behaviors, physical activity and sedentary lifestyle associated with overweight and obesity, and their sociodemographic correlates, among Pakistani primary school children. Int J Behav Nutr Phys Act. 2011; 8: 130.

6. Riset Kesehatan Dasar. Badan Penelitian dan Pengembangan Kesehatan. Jakarta: Kementerian Kesehatan RI. 2007.

7. Riset Kesehatan Dasar. Badan Penelitian dan Pengembangan Kesehatan. Jakarta: Kementerian Kesehatan RI. 2010.

8. Gupta, N., Goel K., Shah P., \& Misra, A. Childhood obesity in developing countries: Epidemiology, determinants, and prevention. Endocrine Reviews (EndoJournals). 2012; 33(1): 48-70.

9. Arisma, M.B. Obesitas, diabetes melitus, \& dislipidemia: Konsep, teori, dan penanganan aplikatif. Jakarta: EGC. 2011.

10. Centers for Disease Control and Prevention (CDC). School health guidelines to promote healthy eating and physical activity. Morbidity and Mortility Weekly Report (MMWR). 2011; 60(5): $1-53$.

11. Erika, K.,A. Contribution of lifestyle and obesity to the incidence of pre-diabetes. Folia Medica Indonesiana. 2010; 46: p.263-269.

12. Gupta, R.S., Shuman, S., Taveras, E.M., Kulldorff, M., \& Jonathan, A. Opportunities for health promotion education in child care. Pediatric. 2005; 116: 499.

13. Barlow, S.E. Expert Committee recommendations regarding the prevention, assessment, and treatment of child and adolescent overweight and obesity: Summary report, Pediatrics. 2007; 120
(Suppl. 4): S164-S192.

14. Prochaska, J.O., Butterworth, S., Redding, C.A., Burden, V., Perrin, N., Leo, M., Flaherty, R.M., Prochaska, J.M. Initial efficacy of BMI, TTM tailoring and HRI's with multiple behaviors for employee health promotion. Prev Med. 2008; 46(3): 226-231.

15. Tuah, N.A.A., Amiel, C., Qureshi, S., Car, J., Kaur, B., Majeed, A. Transtheoretical model for dietary and physical exercise modification in weight loss management for overweight and obese adults. Cochrane Summaries. 2012

16. Johnson, S.S., Paiva, A.L., Cummins, C.O., Johnson, J.L., Dyment, S.J., Wright, J.A., Prochaska, J.O., Prochaska, J.M., Sherman, K. Transtheoretical model-based multiple behavior intervention for weight management: Effectiveness on a population basis. Prev Med, National Institutes of Health. 2008; 46(3): 238-246.

17. Black, M.M., Hager, E.R., Le, K., Anliker, J., Arteaga, S.S., DiClemente, C., Gittelsohn, J., Magder, L., apas, M., Snitker, S., Treuth, M.S., \& Wang, Y. Challenge! Health promotion/obesity prevention mentorship model among urban, adolescents. Pediatrics. 2010; 126:280-288

18. Foster, G.D., Sherman, S., Borradaile, K.E., Grundy, K.M., Veur, V., Nachmani, J., Karpyn, A., Kumanyika, S., \& Stephanie S.J.S. A policy-based school intervention to prevent overweight and obesity. Pediatrics. 2008; 121: e794-e802.

19. McCarron, D.A., Richartz, N., Brigham, S., White,M.K., Stephen, P., Klein \& Kessel, S.S. Community-based priorities for improving nutrition and physical activity in childhod. Pediatrics. 2010; 126:S73-S89.

20. Golan, M., \& Weizman, A. Familial approach to the treatment of childhood obesity: conceptual model. Journal of Nutrition Education 01.2001

21. Potter, P.,A., \& Perry A.,G. Buku ajar fundamental keperawatan: Konsep, proses, dan praktik. Vol.1. E/4. Jakarta: EGC. 2005

22. Williamson, W., \& Kautz, D.D. Increasing awareness in African American BSN students of the health risks of obesity. The ABNF journal: official journal of the Association of Black Nursing Faculty in Higher Education, PubMed. 2013; 01/24(2):40-1

23. Jones, V.M., Miller, C.S., Dorn, J.A.R., Johnson, B., Overall, M., \& Dwyer, K. Health information technology use and health literacy among community-dwelling African Americans. The ABNF journal: official journal of the Association of Black Nursing Faculty in Higher Education, PubMed. 2013; 01/24(1):10-6

24. Fattah, M. Molecular mechanism of association between obstructive sleep apnea with endothelial dysfungtion and cell death: A study of oxidative stress and inflamation. Disertasi. Makassar: Universitas Hasanuddin. 2012.

25. Yilmaz, F.M., Yilmaz, G., Savas E.S., Dallar, Y., Topkaya B.C., \& Yucel, D. Serum sialic acid, hs-CRP and oxidative stress parameters in obese children. J Pediatr Endocrinol Metab. 2007; 20:205-210.

26. Agirbasli, M., Cakir, S., Ozme, S., \& Ciliv, G. Metabolic syndrome in Turkish children and adolescents. Metabolism. 2006; 55: 1002 1006.

27. Pedrozo, W., Rascon, M.C., Bonneau, G., de Pianesi, M.I., Olivera, C.C., de Aragon, S.J., Ceballos, B., \& Gauvry, G. Metabolic syndrome and risk factors associated with life style among adolescents in a city in Argentina, 2005. Rev Panam Salud Publica. 2008; 24: 149-160.

28. Esmaillzadeh, A., Mirmiran, P., Azadbakht, L., Etemadi, A., Azizi., F. High prevalence of the metabolic syndrome in Iranian adolescents. Obesity (Silver Spring). 2006; 14: 377-382.

29. Caceres, M., Teran, C.G., Rodriguez, S., \& Medina, M. Prevalence of insulin resistance and its association with metabolic syndrome criteria among bolivian children and adolescents with obesity. BMC Pediatric. 2008; 8:31

30. Wong, D.L. (2004). Wong and Whaley's Clinical Manual of Pediatric Nursing, 4th Edition. Missouri: Mosby Inc. 